\title{
PLAGUE, SANITARY ADMINISTRATION AND THE END OF EMPIRE
}

\section{INTRODUCTION}

The Ottomans had fully embraced a new vision of plague and quarantines in the wake of the 1894 and 1897 International Sanitary conferences. This vision of disease indeed accepted Alexander Yersin's 1894 discovery of the bubonic plague bacilli in Hong Kong as valid for justifying hygienic measures that sought to eliminate the ultimate cause of the disease: the filthy, unsanitary living conditions of 'unmodernised' societies. The only way the disease in question could be defeated was through governmental action. This meant establishing a sanitary administration that would not only establish hospitals to treat the sick through vaccinations and other modern treatments, but also constantly police the impoverished and marginal. As seen in the previous chapter, the Europeans after 1838 often saw Middle Eastern Muslims - particularly the people of Egypt - as the uncivilised bearers of infectious disease. Such a view helped to support the long-term British and French aim to colonise the country, given the implication that only the Europeans were civilised enough to establish an effective sanitary administration of the area.

The Ottomans, convinced by developments towards the end of the century - the establishment of the European-dominated Suez Canal in 1869, the British defeat of Urabi Revolt and the establishment of a protectorate in 1882, and the International Sanitary Regulations of 1894 and 1897 - had now decided to adopt an infectionist view of plague and other epidemic diseases.

A 1908 Ottoman imperial edict declared that they could not limit their activities to policing ports and the docks, granaries and storehouses connected to them through the maritime quarantine. The government was also now empowered to 
inspect, repair and rebuild sewers and even private homes: 'Above all we must get rid of the filth that allow rats into a city.' ${ }^{1}$ This meant above all to police the poor:

Patients who have come down with plague are to be sent for quarantine to prison-like cells for solitary confinement. Their clothes and undergarments will be destroyed or put inside metallic boxes encased in solution ... [Their houses must also] be emptied ... The houses should be burned along with their furniture if they are of little value. Their prior inhabitants should be sent far away and examined in tent-hospitals. There their goods would be subject to disinfection procedures. [Even if the houses are of value], no one can live [there] for two months; the municipal or state government will have to provide a place for the inhabitants to live. ${ }^{2}$

These measures were implemented in urban areas throughout the empire. Hospitals, vaccination centres, sewers, plumbing and building codes were, of course, established in Istanbul - the capital of the empire, which over the course of the nineteenth and early twentieth centuries was filled with recent Muslim refugees from the wars that bedevilled the Balkans and Caucasus.

Yet an even more remarkable effort was made in the Middle Eastern provinces, particularly Ottoman Iraq and the Hijaz, where the policing efforts involved social and religious groups that historically were only partially integrated into the Ottoman state.

Iraq was of growing international importance. Its southernmost province of Basra was envisioned to be the terminal station of the famed Berlin to Baghdad Railway, a project which would have allowed both the Ottomans and their German sponsors to bypass the Suez Canal by a new rail route. The Ottomans and Germans, as well as their British rivals, were also increasingly aware of Iraq's untapped petroleum resources - vital to nearly every aspect of the industrial age. The railway, begun in 1903, was only in its initial stages of construction, and the Ottomans sought alternative means to try to consolidate rule in the distant province. These efforts were complicated by the Shiites of the region, who travelled to southern Iraq each year on an annual pilgrimage to the holy cities of Najaf and Karbala. The Ottomans, perhaps fearful that their local Shiite minority would become increasingly restive in their desire to unite with their numerous foreign co-religionists, called on sanitary measures to control the incoming Shiite pilgrims - especially from Persia.

The Ottomans were also greatly concerned with the Hijaz, the western Arabian province that was home to the two holiest cities of the Islamic world, Mecca and Medina. They faced growing criticism by foreign observers that 
plague was running rampant there. One British physician noted hundreds of deaths from plague in outbreaks between 1906 and 1908 and urgently called for international action to stem further outbreaks. ${ }^{3}$ His criticism was painful, given the geopolitical realities of the time. Britain, having declared a protectorate over Egypt and the Suez, had nearly complete naval dominance over the Red Sea and eastern Mediterranean. British influence was bound to grow, especially in the Hijaz port cities of Jeddah (64 km from Mecca) and Yanbu al-Bahr (164 $\mathrm{km}$ from Medina). By 1900, the Ottomans felt compelled to embark on another railway project - the Hijaz Railway - to link the province by rail to the rest of the empire. The British and other European powers repeated their earlier concerns about the threat of epidemic disease, especially as it related to the annual Muslim pilgrimage. The Bedouins of the province were also worried that the railway would diminish their incomes, as they collected annual subsidies from the Ottoman government and fees from the pilgrims for providing goods and safe passage. While the Ottomans completed the Damascus-Medina stage in 1908 and planned to extend the railway to Mecca, they also sought other means to consolidate rule in the cities of the Hijaz: the sanitary administration.

The leading Ottoman sanitary administrative official for both of these projects was Kasım İzzeddin (1858-1926). From 1894 until 1912 İzzeddin was involved with the quarantine and sanitary efforts in Mecca, as well as in Baghdad and Basra, and was appointed to a variety of posts during this time, including Inspector General of the Ottoman Sanitary Administration, Director of the Hijaz Sanitary Administration and Chief Sanitary Officer of the Quarantine at Baghdad, Basra, Damascus and Sinop. It was no accident that the bulk of these posts were in the Arab provinces of the Ottoman Empire. İzzeddin was a Lebanese Sunni Muslim, very much concerned that his home province, like Palestine, Syria and Iraq faced the threat of colonisation by the British and the French. Such feelings were revealed in the 1911 International Sanitary Conference held in Paris, where he, as Ottoman representative, raised the issue of religious equality. If a sanitary administration was necessary for the Muslim pilgrimage in the Hijaz on the principle that such meetings of pilgrims from faraway places could introduce new epidemic diseases, he asked, why should sanitary administration not be necessary for every pilgrimage? Thus, in his opinion, the Ottomans should run a sanitary administration not just in the Hijaz for Sunni Muslims, or in Najaf and Karbala for Shiite Muslims, but also in Jerusalem for Jewish and Christian pilgrims. He followed this up with arguments to tighten international restrictions on vessels approaching Ottoman ports in the eastern Mediterranean from 'infected ports' which would allow the Ottomans to medically inspect and detain boats of Jewish immigrants and pilgrims from Russia. ${ }^{4}$ Although İzzeddin's effort to change the regulation was unsuccessful, it was likely appreciated by other key Ottoman 
sanitary administrative officials, such as Ruhi Al-Khalidi (1864-1913), a leading Arab Young Turk supporter from a prominent Palestinian family, who was one of the first to call attention to the increasing Zionist presence in his homeland. Khalidi's insistence that the newly-created Hijaz Sanitary Administration be directly controlled by the Ottoman central government through the Interior Ministry was also a telling moment. Khalidi, like İzzeddin, invested his hopes in centralising rule in the region, since the Ottomans then would be even more committed to retaining sovereignty in the north-eastern Arab provinces, as they linked Anatolia to both Iraq and the Hijaz. ${ }^{5}$ Opposition to the sanitary reforms carried out by İzzeddin would be quite sharp, particularly on the part of local Shiites and Bedouins.

The British had a very curious reaction to these developments. Dr Frank G. Clemow, the British Representative to the Constantinople Superior Health Council and the Crown's Delegate to the 1911 International Sanitary Conference, often applauded İzzeddin for adopting an infectionist understanding of plague and other epidemic diseases, and supported many of his sanitary reforms. These reforms would often involve new technologies, such as water supply and fumigation, that would potentially increase Ottoman dependency on London for both finance, technological know-how and even energy dependence on coal supplies. His attitude, like that of the British Empire, would only change during the First World War, when the British cut their support and started to foment rebellion among the Shiites and Bedouins.

The following chapter will examine the continuing dialogue İzzeddin and Clemow had on sanitary reform in both Iraq and the Hijaz from the beginning of the twentieth century until the outbreak of the First World War, and detail the consequences of the reforms during and after the ensuing conflict.

\section{THE OTTOMAN SANITARY DEFENCE OF IRAQ AND THE PERSIAN GULF}

İzzeddin was not the first Ottoman sanitary official to face serious challenges on the Empire's eastern frontiers with Persia and the Gulf. The Ottomans had first set up quarantine stations to prevent the spread of plague and cholera after the 1851 Paris International Sanitary Conference. Ottoman officials had argued that epidemic diseases often passed into the empire through Persia, as witnessed by the 1831 plague outbreak there. Further epidemic outbreaks of plague and cholera occurred throughout the 1860s and 1870s, and Ottoman and Persian officials often blamed each other as the first country to have the disease. Dr Bartoletti, who represented the Ottoman Empire at the International Sanitary conferences in the decades before İzzeddin took office, accused the Persians in 
1871 of turning a blind eye to plague cases in their country. He thought that a land cordon should be set up along the Ottoman-Persian border, and helped to supervise the establishment of two main stations at Khanikin, along the main southern Persian road to Baghdad, and at Bayazid in the mountainous north. $\mathrm{He}$ and the Ottoman government believed that the main carriers of the disease were the northern mountainous nomads and the Shiite pilgrims who made an annual trek to the holy cities of Najaf and Karbala, and also nearby Baghdad. ${ }^{6}$ Representatives of the Persian authorities, such as Tholozan, the founder of the Persian Sanitary Council in 1868, claimed that the Ottoman nomads of northern Iraq were to blame for outbreaks of plague and cholera. In his opinion, the Ottomans should cease their criticisms, and the needless land cordon, and work to improve sanitary conditions among the nomads instead. ${ }^{7}$

The Ottomans also set up two key maritime quarantine stations in the region after 1851. The first was at Basra, the southernmost Ottoman port in Iraq, and also at the Hormuz, key to controlling access to the Persian Gulf. Indian Shiite pilgrims to southern Iraq - also declared a high risk group for plague and cholera - justified the existence of these stations even into the first decade of the twentieth century. The 1903 Sanitary Convention directed that all ships entering the Gulf be subjected to medical inspection at Hormuz. Those entering the Ottoman Empire had to undergo a second inspection at Basra: any vessel which had previously docked at a port with confirmed cases of plague or cholera was required to complete five days observation before being allowed to go. ${ }^{8}$

Yet it was only during İzzeddin's time that these arrangements fundamentally changed. İzzeddin and the Ottoman government set the tone when, under international pressure, they abandoned the quarantine station at Hormuz. Clemow claimed that British-run alternative quarantine stations in the Gulf 'rendered wholly unnecessary any special clauses in the conventions for the sanitary defences of the Persian Gulf'. ${ }^{9}$ This shift revealed Great Britain's near total maritime domination of the Gulf.

İzzeddin thus limited his efforts to the Basra, Khanikin and Bayazid stations. Of these three, Basra was the most inconsequential. Between 1903 and 1913, an average of only 3,334 people entered the Ottoman Empire at Basra, compared with an annual average of 42,031 entering the Ottoman Empire from Persia. ${ }^{10}$ The Khanikin station alone processed about two-thirds of the Persian traffic to the Ottoman Empire. The station also played an important financial role, since they charged a sanitary tax of 10 piastres for every Shiite pilgrim who crossed the border. The bulk of the foreign pilgrims were Persians, although a significant number of Russian Shiites also passed. ${ }^{11}$

The greatest controversy concerning the pilgrim traffic revolved around the pilgrims' tradition of burying their deceased loved ones at Najaf and Karbala. 
The Ottomans had generally restricted the practice to only those 'dry' corpses that had mummified, since they suspected 'fresh' corpses of transmitting plague and cholera. The only exception to this rule was the bodies of those who had died only twelve hours prior to crossing the border. The Ottomans collected a sanitary tax of 50 piastres per corpse, five times that for a live pilgrim. This resulted in a substantial amount of income, as evidenced by an annual average of 3,900 bodies taken across the border at Khanikin between 1909 and $1914 .{ }^{12}$ These numbers peaked in 1912-13, when, under İzzeddin's supervision, the Ottomans collected taxes on a record 7,558 corpses.

The tax was controversial. Clemow, for instance, dismissed Ottoman concerns that the bodies might spread disease:

While disease has been repeatedly introduced and spread by the movements of the Shiite pilgrims, it is noteworthy that it has apparently never been so by the movements of the Shiah corpses. No instance could be traced in which either plague or cholera - the two diseases mainly dealt with under the international conventions - had been imported or diffused by these dead bodies. ${ }^{13}$

Clemow suspected that local Ottoman officials were seeking to exploit the pilgrims for their own monetary gain, as seen in his own description of the practice in Najaf:

On arriving in the outskirts of Najaf the bodies are first deposited in a small enclosure, or morgue, built in the desert near the town. Here the taxes are collected; the bodies are removed from their outer wrappings or coffins, and placed in large coffins belonging to the defnieh department (the nature of which will be defined shortly). The other wrappings and coffins are burned by the health officials, in the desert near the morgue. The commission was consulted as to the necessity of continuing this system of incineration. The labads or shibna - that is, the shrouds around the coffins - are of considerable value, and the wood of the coffins would be precious in these regions, where trees are unknown and all wood has to be imported. The local authorities were anxious for permission to arrange for the preliminary disinfection of the coffins, which they then proposed to sell; the revenue thus obtained would, they claimed, enable the local health assembly to put up a steam disinfecting stove, in which the shrouds also be disinfected and afterwards sold. Some such form of disinfection was attempted a few years ago, but it led to serious abuses and was abandoned. The commission definitely condemned a return to the former system. The practical difficulties in the way of properly disinfecting a large number of coffins and shrouds would be considerable, and, for obvious reasons, incineration is the only proper fate of such objects. ${ }^{14}$ 
The pilgrims and the local Shiite population subverted the Ottomans by propagating a 'sanitary contraband in dead bodies':

It is not rare for corpses to be brought secretly, at night, accompanied by armed bands of Arabs or Kurds, numbering some scores or even hundreds, who buried corpses in the cemetery outside the town without any formalities being complied with. Such contraband will always exist, for it could only be met by using armed forces superior to the others, and in each instance many lives would probably be sacrificed. Contraband in fresh (and dry) bodies was largely exercised by persons in the holy cities who made a profession of the practice. It seems that all the principal towns in Persia and Mesopotamia had representatives or commissioners in the Shiah cities; they were generally gravediggers, muleteers, khan-keepers [shopkeepers], khadims [pilgrim-guides], and even sayyids [descendants of the Prophet] and ulemas [Islamic theologians]. The bodies were addressed to such commissioners, who would go out into the desert to meet them and give the bearers of false certificates, testifying that death had occurred within the 12-hour zone. $^{15}$

Clemow thus recommended that the Ottomans focus on the live pilgrims alone as the main concern of their medical inspections.

Moreover, he also drew attention to the poor hygienic state of affairs in Ottoman Iraq. Besides pointing out the endemic nature of the Tigris and Euphrates river valleys as their damp soils often caused putridity and disease among the houses and settlements there, he highlighted the need for better sanitary measures in central and southern Iraq. He remarked that 'there [were] no drains in Karbala or Najaf'. Most of the houses had cesspools and, in his opinion, 'it [was] not surprising that many diseases are rife in [these] cities' ${ }^{16}$ To him, Basra was also highly problematic, as water supply for this town of 50,00060,000 people was directly from nearby creeks contaminated by surface pollution. There was no municipal drainage system, and this muddied the unpaved streets with sewage. ${ }^{17}$

Basra was also in dire need of modern building codes. The city's 'sunburned and kiln-burned brick' houses were in bad repair. They were allegedly also badly ventilated and overcrowded. Some dwellings even had strange underground cellars:

In all the larger houses are found underground chambers, or serdabs, where the inhabitants may escape from the great heat of the summer; many are forty or fifty, and some even eighty or 100 feet below the ground. If reports be true, these cellars are often the scenes of unspeakable vices. ${ }^{18}$ 
İzzeddin largely concurred with Clemow on the need for sanitary reform in these cities. After being assigned as the Chief Sanitary Officer of Baghdad in 1905, he established a main office in that city, as well as the major towns of Najaf, Karbala and Kiazimein. Satellite branches were also established at AliEl-Gharbi, Amara, Bugheila and Gourna on the Tigris, and Kufa, Museyyib, Samawa and Shenafieh on the Euphrates. They were staffed by sanitary doctors, police and administrative officials under the supervision of the Ottoman Interior Ministry and the Constantinople Superior Health Council. ${ }^{19}$ İzzeddin did not just 'report to Constantinople [on] the appearance of plague or cholera in their district', and enforce the tax codes and regulations on the pilgrims and the traffic in corpses, as Clemow supposed. He also established major hospitals and enforced new housing regulations in Baghdad, Najaf and Karbala. ${ }^{20}$

İzzeddin also agreed with Clemow that poor sanitary conditions often involved lawlessness. For instance, he blamed the notables of Najaf and Karbala for their involvement in the contraband trade in corpses. He also was concerned that the influx of poor pilgrims from Persia disturbed genuine pilgrims. ${ }^{21}$ This revealed a new attitude among the Ottoman authorities towards outbreaks within the realm. Enacting sanitary policing measures led to social discrimination against the poor and religious discrimination against non-Sunni Muslims.

İzzeddin was frustrated by budgetary and logistical concerns, however. The Ottoman government was forced to foot most of the bill for the sanitary reforms, since the Constantinople Superior Health Council - a nominally international body - could not use the income from the Shiite pilgrim taxes without the consent of its foreign members. Getting up-to-date equipment for the projects, and bringing in sufficient numbers of engineers and construction crews, was also a problem since the railway project was nowhere near to being completed - it remained some $563 \mathrm{~km}$ away from Baghdad in 1918, long after İzzeddin's service in Iraq had ended. ${ }^{22}$

Nevertheless, İzzeddin did manage to worsen relations with the local population. Local Shiites and pilgrims resented higher taxes and regulation. This was often aggravated by the fact that a number of the medical officials were nonMuslims hired from abroad. Lamec Saad, a German-born quarantine official who worked at the Khanikin border station in the early twentieth century, was accused by one Persian Shiite who complained that: 'We are Muslims and not infidels. We do not want to go in quarantine and pay the money. ${ }^{23}$ This complaint much recalled that of İbrahim Rifat Paşa, the Egyptian general who protested at the humiliation of Sunni Muslim pilgrims by Greek doctors at the Tor quarantine by the Suez Canal. Such humiliations prompted action against the quarantine and the government who ran it. The only difference was that this time the Ottomans were on the receiving end, an ominous sign for rebellion in the years ahead. 


\section{SANITARY REFORMS IN THE HIJAZ}

Issues about quarantine, medical inspection and sanitary administration was be on a much greater scale in the Hijaz. This was reflected in the 1911 Paris International Sanitary Conference, where İzzeddin and Clemow represented the Ottoman and British sides, respectively. The Ottomans and British sought to reach accommodation on several key issues; first and foremost, how the Conference's sanitary regulations related to the Hijaz Railway project. The Hijaz Railway greatly concerned the British after 1908, since it allowed pilgrims from the Empire and beyond to bypass the British sanitary controls at the Suez Canal. Clemow and his government feared that the annual number of 12,000-20,000 pilgrims that used the route could spread cholera and plague to the Hijaz, elsewhere in the Ottoman Empire, Europe and beyond if adequate medical inspection facilities were not implemented along the route. Austro-Hungarian, French, Dutch and Italian delegations shared the British concerns since they, too, had many Muslim colonial subjects of their own who used the route. Yet the Ottomans firmly resisted any formal international sanitary control over the railway. As Ali Mukhtar Bey, İzzeddin's fellow countryman, related at the Conference: 'The Ottoman government considers the Hijaz Railway as an interior line and does not believe it is more dangerous than rail lines found in other countries.' Clemow and the majority of the Conference conceded that the Ottoman Empire had the right to run its own sanitary administration within the borders of the country. ${ }^{24}$

This quick approval was the result of a joint Ottoman-British effort to achieve international consensus on the subject. The British sought to influence Ottoman policy on the Hijaz Railway and the Ottomans needed to get Great Britain's consent to use sanitary tax revenues to develop a sanitary administration in the area. İzzeddin began this cooperation in 1908 when he helped form a joint ad hoc committee with Clemow to select a new quarantine station on the railway line. Clemow and the other foreign powers agreed to fund the effort temporarily, pending discussion at the Conference. They set up their temporary quarantine at Medain-i Salihi, a town roughly $350 \mathrm{~km}$ to the north of Medina. The Ottomans recommended the site as it was situated on the northern border of the Hijaz, and would thus fit well within current administrative divisions. İzzeddin, the committee and the local Ottoman sanitary officials established a makeshift medical camp, and work was done to supply food, water and shelter to the 12,933 pilgrims who were inspected that year at the station for plague and cholera. Cholera was diagnosed in 101 pilgrims, fifty-seven case of which were fatal. İzzeddin felt that despite improvisations, awkward planning and occasionally mismanaging these infections the mission was ultimately successful, as 'the disease did not spread [from the Hijaz] to Syria' ${ }^{25}$ 
Clemow raised doubts about choosing Medain-i Salihi as the permanent site of the railway quarantine. He argued that the water supply to the town was too poor and was very vulnerable to sandstorms - factors that forced the committee to establish the quarantine $10 \mathrm{~km}$ away from the railway, causing further delays for the travellers. He was also worried about resistance from local Bedouins to reforms. He saw this firsthand when: 'On the day of our arrival there was a serious attack made on the head of the [rail] line and in the fight which followed some forty Bedouins were said to have been killed. ${ }^{26}$ To him, the Bedouins' resistance to the quarantine stemmed from their belief that the Prophet Muhammad himself had forbidden outsiders to stay in the town:

Medaini Salih is, to those Muslims who know the legend that gives it its name, more or less under a ban... As far as can be gathered the legend is not known to the bulk of the pilgrims and it did not apparently lead to any overt objection on their part to the choice of Medaini Salih for the temporary lazaret in the last two seasons. Possibly it might not lead for many years to come to any difficulties in connection with a prominent lazaret here. But there would always be the risk of its doing so someday. Pilgrims in any case admit unwillingly to a quarantine, and should any fanatic among them choose to recall the legend (which is referred to frequently in the Koran) and incite the other pilgrims to rebel against being quarantined here, a very serious condition of affairs might be brought about. It might easily become impossible to force the pilgrims to remain here and quite possibly they would take the law into their hands and destroy the buildings. As it is intended to spend large sums in installing the new lazaret, it would be foolish to run this risk, more particularly as the transfer to another side of a lazaret, once built, is as costly (indeed it would practically mean) its rebuilding anew. ${ }^{27}$

Clemow argued that the Ottoman quarantine station should instead be established in Tebouk, a town also on the Hijaz Railway roughly $283 \mathrm{~km}$ north of Medain-i Salihi. He believed that the town had a much safer water supply, better quarries and was less prone to sandstorms. He also argued that the quarantine station at Tebouk could be established much closer to the railway than at Medain-i Salihi. In his opinion, the place was also a strategic location, as the Bedouin tribe, Beni Attiyeh, had a good working relationship with the Ottoman authorities there. ${ }^{28}$

İzzeddin concurred. He agreed that water could easily be brought to the Tebouk station and did not foresee any great administrative difficulties for the Ottoman sanitary administration. Although he did not explicitly mention the issue of the Bedouins, he was no doubt aware that the Bedouins around Medain-i Salihi violently protested the quarantine station out of fear that the government 
would soon interfere with their tribal affairs. ${ }^{29}$ From İzzeddin's viewpoint, moving the station to Tebouk would cause fewer possible complications, as the Bedouins there were much more amenable to the increased governmental presence.

The Ottoman quarantine station was quickly constructed in Tebouk the following year in accordance with Clemow's recommendations. İzzeddin noted that in 1909 there were only three cases of cholera seen in Tebouk and that the disease again did not spread to Syria. ${ }^{30}$ Clemow and İzzeddin had basically worked out an arrangement on the Hijaz Railway station before they arrived at the Conference. İzzeddin would follow Clemow's instructions on how and where to establish the station, but the Ottoman sanitary officials would run it, partially funded by the sanitary taxes. The Conference merely ratified this arrangement.

The Ottomans also faced considerable pressure from the Europeans to make sanitary reforms in the major towns of the Hijaz, particularly Mecca and the adjacent Red Sea port of Jeddah. Proust complained about Jeddah after 1894 that:

One should note the filthiness of the town. The Ottoman government does not take responsibility, as pilgrims who disembarked from [the Ottoman quarantine at] Kamaran are crowded into rooms of more than thirty people. Garbage was strewn throughout the streets, and then never cleaned. The government collects municipal taxes of fr.175,000 per year but no work is done. ${ }^{31}$

Proust saw İzzeddin's efforts at that time to send professional medical teams, restore water pipes and build fumigation stations in Jeddah, construct a 1,400-bed guest house and three hospitals in Mecca and clean the streets of Medina as laudable, but ultimately unsuccessful. ${ }^{32}$ In May 1895 'local Bedouins' assassinated Abdur-Razzack, the British Vice Consul for Pilgrimage Affairs in Jeddah, and wounded the British, French and Russian consuls in protest at the measures. ${ }^{33}$ Thereafter the municipal sanitary workers neglected their duties and the local Muslims of Jeddah allegedly polluted the new water supply when they performed ablutions and washed their linen. ${ }^{34}$

İzzeddin himself conceded that his early efforts were not enough. He agreed that the local municipal government could not handle these efforts on their own, as 'epidemic diseases occur during the pilgrimage', affecting far more than just the provincial population. The locals also did not have either sufficient funds or capable officials to administer the reforms. He documented this with a May 1910 report from Zihni Pasha, the Ottoman Governor of the Hijaz to the Ottoman Interior Ministry. The Governor mentioned that Hussein Bin Ali (1854-1931), the Sharif of Mecca, could only raise 50,000 paistres as sanitary tax, and that 
nothing more could be expected from them or the local Bedouins whom he represented:

Everyone is thirsty and hot, both during the pilgrimage - when the blessed die - and during the off-season [when the region] is continually crowded with more than 100,000 people. [The Hijaz] is truly a gathering place for the entire Islamic world, no matter what time. Only the Ottoman state can maintain order for the Muslim pilgrims who come from every end of the earth. It must do so with its funds and personnel as agriculture and industry do not exist, and trade is limited. ${ }^{35}$

In İzzeddin's eyes, the Ottoman government should assume direct control since state treasury funds would be involved. In fact, the Ottoman government approved a budget of $3,184,703$ paistres - roughly comparable to that of the Hijaz Railway. ${ }^{36}$ It expended 1,275,280 paistres from the central treasury to pay for the sanitary reforms, a far higher amount than the 50,000 paistres taken from local taxes, or even the 130,000 paistres it raised from foreign pilgrims. The government's fiscal commitments underscored its claim that the reforms were its holy duty: 'The administration of the pilgrims' sanitary affairs is incumbent upon the exalted government and the Islamic Caliphate. ${ }^{37}$

İzzeddin and his co-administrators elaborated these arguments when they launched the Hijaz Sanitary Administration in 1910:

The Hijaz Sanitary Administration is providing great service to the Islamic world. There is no doubt that the people who have died in the Hijaz surpasses many times over the casualties of great battles ... Consequently, it is necessary for the Hijaz Sanitary Administration to undertake such a holy duty to help the sick, like the wounded on the battlefield ... It is natural that the number of pilgrims will increase as long as we protect their health and well-being. If we do so, Muslims will joyously come here to fulfil their sacred duties. We will be rewarded for this in the next world ... We have a responsibility to the more than 300 million Muslims of diverse nations and tribes who gather here in brotherhood. We need to advance their health, social and economic well-being, and show the superiority of Islam. This would demonstrate how knowledge, civilisation and the economy could be used to achieve God's will. But how is that possible when 100,000 Muslims come here without food, drink, shelter, and are unprotected and unclean? In short, they lack sanitary precautions and thus help spread contagious disease. The building of more residences for the pilgrims worsens the situation. Only the Hijaz Sanitary Administration can address these problems and gradually improve living conditions. ${ }^{38}$ 
The new administration embarked on a variety of reforms, including the establishment of sanitary police and engineers, medical personnel, permanent hospitals, tent-hospitals, pharmacies, fumigation stations, administrative buildings, shelters for poor pilgrims, new sewage, water supplies, and new building and food regulations for all four major cities in the Hijaz (Mecca, Medina, Jeddah and Yanbu).

The Hijaz Sanitary Administration had now become another branch of the Ottoman central authority. İzzeddin, the Director of the Hijaz Sanitary Administration, worked in the name of Talat Pasha (1874-1921), the Interior Minister, much like the Director of the Hijaz Railway did. The directors of the Hijaz Sanitary Administration and the Hijaz Railway both tended to clash with Hussein, the Sharif of Mecca, whom İzzeddin ironically thanked for running the Jeddah sanitation efforts prior to his arrival. His dismissive attitude towards Hussein's municipal authorities - the local notables and Bedouins - was telling. New regulations required Hussein not only to obey İzzeddin as the Director of the Hijaz Sanitary Administration, but also to send him an annual report on how İzzeddin's reforms were implemented in the province. ${ }^{39}$

İzzeddin and Clemow discussed sanitary measures in Jeddah in some detail, particularly regarding the establishment of new hospitals and water supplies. The European powers paid great attention to Jeddah, since it was the major port of the region, and, as such, had the strongest foreign presence. Clemow complained that Jeddah's one working hospital was 'quite inadequate to the needs of the place':

There is a small municipal hospital situated inside the wall that completely surrounds the town on its eastern side and not far from the Mecca gates. It is a onestory structure built against the town wall. It contains two wards for twelve and eight patients respectively; the wards have no flooring, their floors being a beaten earth. Close by is a wooden shed in bad condition used for dysentery patients; it is almost entirely without furniture. In brief, this hospital - though those in immediate charge of it have apparently done their best with limited means placed at their disposal - is altogether too small and too primitive for a town like Jeddah, with its vast floating population. The inspection commission in its report consequently urges the Turkish government to build a large general hospital capable of 150 or 200 patients and suggests a suitable site where it might be built. ${ }^{40}$

İzzeddin apparently received far harsher criticism from other foreign officials:

There was ... no hospital in Jeddah, except for the city hospital, which foreign embassies complained about numerous times. One stated: 'The Jeddah hospital is 
only a single wooden barrack. There are no hospital attendants, food or water. It has wooden stumps for beds, with holes in it for the patient to relieve themselves. For this reason, human excrement has piled up on the floor. The place is like a dunghill. Your patients suffer from various diseases like smallpox and dysentery. The place simply spreads disease among the patients'. The Consul sent a picture of the hospital where six patients - three with smallpox - were lying down on a wooden stump. There also was a picture of a funeral of a man who died a day ago. The procession was covered with flies, and one could see the human excrement under the wooden stumps. ${ }^{41}$

İzzeddin worked quickly to address these concerns. Two hospitals, one a 100-bed military barracks facility, and the other a forty-bed tent-hospital were established within the first year of the Hijaz Sanitary Administration. ${ }^{42}$ Izzeddin's success in establishing the hospitals without incident was remarkable given the assassination of Abdur-Razzack in 1895 in protest against fumigation stations that were erected in the city. ${ }^{43}$

The establishment of new water facilities in Jeddah proved to be more difficult. The city had suffered a drought in 1906, when Clemow had inspected the facilities. Water in Jeddah at the time he visited was basically limited to rain water, which individuals in Jeddah had collected in tanks and cisterns throughout the city, and numerous wells which had been dug near the city walls. The water from both of these sources was extremely poor in quality, and quite unhealthy to drink - especially the brackish well-water. There were four other springs outside the city, but only one of them, Ayn Bariman, was able to provide the city with any water. Ayn Bariman's water was carried 'by petroleum cans on the back of a camel or donkey'. The other three springs, Ayn Farraj, Ayn Hamidiye and Ayn Veziriye, had water pipes to the city, but they were constantly sabotaged. ${ }^{44}$

Clemow cited local opposition against water supplies as the main obstacle to reform. He suspected 'certain citizens of Jeddah', [who] own the majority of the water tanks', were the ones actually behind the Bedouin attacks. Led by local notables like 'Hadrami - a very influential man who opposes all efforts made in order to improve the situation', these interests had damaged the water pipes in an attempt to retain their monopoly over the cistern water and the Ayn Bariman springs. ${ }^{45}$

Clemow proposed establishing water-distilling machines to process local well and rainwater. This would alleviate the need to rely on the local cistern interests, and would avoid the nearly impossible task of securing pipelines to the wells outside the city - since they would remain vulnerable to attack. Though the distilling machines were presumably safe behind the guarded walls of the medical facilities, the Ottomans were still wary of further opposition: 
Vested interests are extremely strong; the owners of tanks will do all they can to prevent the sale of distilled water, if they do not actually attack the machines. The people themselves, strongly conservative by nature, will take time to get accustomed to distilled water in place of the other waters they have been used to drinking. In time, however, there should be no question of the distiller or distillers, under proper management, yielding a handsome annual profit. This aspect of the question is, however, in truth, one of secondary importance in comparison with the real necessity, on sanitary and humanitarian grounds, of providing Jeddah with a certain, abundant, and safe water supply. ${ }^{46}$

Clemow felt, however, that popular suspicion of the distilled water could be overcome in time, especially given its higher quality and cheaper price. He cited his own government's success in establishing a similar machine in Oman, where the locals fought over the distilled water once they had tasted it. ${ }^{47}$

İzzeddin followed up on Clemow's suggestions by buying a water distiller (100 tons per day), and a large ice-maker (2,000 kg per day), along with the electrical cables and equipment to run both machines. ${ }^{48} \mathrm{He}$ also accessed a new water source only $5 \mathrm{~km}$ to the north of Jeddah to supply the distillation and ice machines. They were secured within his sanitary compound. ${ }^{49}$ Much of the city celebrated:

In January 1329 [1911], they completed installing the ice machines and electricity generators [in Jeddah]. The government officials held a ceremony with the consulates of the foreign powers, local notables and steamboat agents. They slaughtered rams and prayed that the Caliphate of Islam's glory may be increased. They also wished for the prosperity of the Hijaz Sanitary Administration. The opening day of the ice and electric generators was a joyful one for the people of Jeddah. They opened the doors of the factory to the public and all the people around came to see the machines and were happy. ${ }^{50}$

Such successes were key to convincing both the foreign powers and the local population that the Hijaz Sanitary Administration's programme of social and political centralisation was there to stay. Yet foreign support - particularly that of the British - was vital. İzzeddin had followed Clemow's suggestions on nearly every matter brought to him - be it for the railway quarantine station or Jeddah's hospitals and water supply. İzzeddin also imported the distillation and ice machines from Great Britain over naval routes largely controlled by Great Britain. The coal he required in Jeddah to provide the electricity for the machines also had to be shipped in - as this bulk good could not be brought overland since the railways from Medina to Mecca and Jeddah were not complete. 
Unsurprisingly, the British even suggested that the Ottomans use Cardiff coal instead of domestic coal from Zonguldak on the Black Sea coast. The British claimed that the coal burned cleaner and provided more energy. ${ }^{51}$

Yet the celebratory scene over ice in Jeddah, reminiscent of similar festivities for the Hijaz Railway, ${ }^{52}$ conveyed sovereignty in a concrete way that the pilgrims and the local population were bound to appreciate. The Ottomans under İzzeddin sought to further express this sovereignty in the district through their new-found social disciplinary powers as medical and sanitary inspectors.

Poverty, in İzzeddin's opinion, was a 'difficult social disease for the holy pilgrimage' that bred epidemic disease, and degraded the sanitary and moral climate for everyone in the region. Two beggars had allegedly begun a cholera outbreak in the Hijaz after travelling from Mecca to Medina on foot in 1909. They were not the only ones who caused problems, according to İzzeddin. Poor pilgrims, who numbered approximately 20 per cent of Muslim visitors, often 'began begging and annoying other pilgrims after arriving in the Hijaz' by going from Jeddah to Mecca with their bowls:

They infringe upon the health of the pilgrims and do things which spread disease. When the diseases abound, there are twice as many dead among them than among the other pilgrims. These people do not come to the Hijaz in order to perform the pilgrimage ... You cannot call them by the title Hajji. They do not deserve the respect the real pilgrims do. ${ }^{53}$

İzzeddin's first initiative to deal with the problem apparently ended in failure:

When we formed the Mecca Sanitary Administration in 1312 [1895] we tried very hard to ameliorate the situation for the beggars. We brought them to our hospitals and gave them food and clothing but this did not satisfy them. Instead, the beggars began to act in a hostile manner. They did not know what goodness means. They pretended to be sick and wanted money from those who passed. They did not like it when the Sanitary Administration picked them up from the streets and sent them to the hospitals. ${ }^{54}$

When İzzeddin used a former barracks to house the poor pilgrims after he became General Director of the Hijaz Sanitary Administration in 1910, the beggars continued to resist. Münir Pasha, the Commander-in-Chief of the Hijaz Division, informed him that: "None of the poor pilgrims wanted to stay in the former barracks, saying that it was very far away from the city and the holy places ... But the guesthouse was only two kilometres away [from the city centre]. ${ }^{55}$ 
İzzeddin approved of measures the Europeans had taken at the 1894 Paris International Sanitary Conference. The French, Austro-Hungarians and Dutch strongly supported travelling restrictions, as all three had substantial Muslim colonial populations. Proust, the main French delegate to the conference, 'mentioned that only 60 per cent of the Muslims from Java, 50 per cent of Bosnian pilgrims and only a few thousand French pilgrims returned home'. The AustroHungarians, no doubt influenced by the fact that up to one-third of the Bosnian Muslim population had left for the Ottoman Empire after the 1878 occupation, ${ }^{56}$ sought to use an internal passport system for the pilgrims. The Dutch followed suit by closely examining returning pilgrims with local Javanese Islamic authorities. If the returning pilgrim could not pass a 'test' about his visit, he was subjected to a monetary penalty. ${ }^{57}$

The British also tried to restrict the traffic of their Egyptian pilgrims as much as possible. As Clemow related:

An Egyptian desirous of making the pilgrimage must secure a special passport from the Mudir of his district or the governor of his town. This passport contains a detailed description of the individual and spaces for receipts for quarantine fees and caution money deposited by the pilgrim. The man must then visit the sanitary inspector of his district, who satisfies himself that the passport is in order, so that he will be able to identify the individual on his return. Later, the passport must be signed by the passport officer at Suez on his outward journey, who again satisfies himself that all is in order before embarkation. On his return journey the passport officer at Tor forwards the document directly to the sanitary inspector of the pilgrim's district. On emerging from Tor the pilgrim is given a voucher which enables him to land at Suez and he is then instructed to proceed direct to his home and present himself daily to the sanitary inspector who at the end of seven days hands back to him this passport duly signed in order that he may be able to withdraw his caution money from the local authority. This system may sound a little complicated but it works extremely well in a country where the people are accustomed from time immemorial to obey the orders of the government officials. ${ }^{58}$

Nevertheless, the British were reluctant to adhere to international regulation of Indian Muslims, as this would imply outside interference in their own internal affairs. They thus referred the question to the Ottomans, saying that they would agree to the restriction only if 'the Sultan, acting as the Caliph, [ordered] that no one should go to Mecca from any part of his Empire without obeying this rule'. ${ }^{59}$ The Ottomans, represented at the 1894 conference by Turhan Pasha, maintained that poor pilgrims should not be hindered from performing their religious duty. Nevertheless, Turhan Pasha was willing to refer the question to his government 
for further consideration, since Islamic legal scholars had conflicting positions on the topic.

İzzeddin, the Ottoman Delegate to the 1911 Paris International Sanitary Conference, reversed the previous Ottoman position: he now supported forcing pilgrims to purchase a return ticket prior to their departure to the Hijaz, as well as pressuring wealthy Muslims who sent substitutes to perform the pilgrimage to provide adequate money for the journey. İzzeddin also advocated greater policing measures once the pilgrims reached the Hijaz, since 'leaving the poor pilgrims who came to do their sacred duty on the streets is contrary to Islam and the Caliphate' ${ }^{60}$ Quarantine officials were to medically inspect the pilgrims before and after arrival, and sanitary police made sure that pilgrims were clean. They also would keep 'beggars' off the streets, and inspect the pilgrim's food and accommodations. ${ }^{61}$

İzzeddin's discriminatory statements about the poor in the Hijaz and the policies he took towards them confirm similar sentiments he had shown in Iraq. Acting as a leading sanitary administrative official, İzzeddin made a major departure from earlier Ottoman views on the plague and other major epidemic diseases. He showed that the Ottomans were now willing to use existing social divisions to further their own governmental power.

Yet İzzeddin's sanitary policies conflicted with the local population just as much as they did with poor foreign-born pilgrims. Clemow spoke of this issue when he talked about the spread of plague in the Hijaz in 1907:

It is a remarkable fact that, with the single exception of a fatal case of plague in a Javanese pilgrim, the outbreak in Jeddah has been strictly confined to the native inhabitants of the town... I am inclined to attribute this relative immunity to the fact ... that most of [the pilgrims] live in homes specially built for the purpose, which are surveyed, cleansed and whitewashed and put into order before the arrival of the pilgrims; and that those who are too poor to stop in houses camp out in the open air, where they are little exposed to the infection of the plague either from contact with the inhabitants of the town or with rats. ${ }^{62}$

Clemow blamed the local Arabs for resisting the sanitary reforms:

There seems to have been much difficulty in applying measures for the suppression of the outbreak. The Arab inhabitants dreaded European interference more than the disease; the large majority of cases have only become known to the authorities after death and it is certain that many that recovered were brought to the knowledge of the latter. Scarcely any of the cases have been removed to hospital. When a death from plague has become known the house where 
it occurred has been disinfected ... Shortly after the revival of the disease in January it was proved beyond a doubt that rats were dying from plague and were in all probability the main channel by which the infection was being spread. Small rewards, of the value of one penny, were offered for the bodies of dead rats, but there is no evidence at present that this measure led to any substantial results. The medical staff of the town was strengthened and an ample supply of prophylactic was furnished to them, but the latest reports showed that it was almost impossible to induce the people to allow themselves to be inoculated. In some cases the opposition to the authorities took a more active form and violence was used. In one case a native woman - possibly interpreting too literally the injunction to keep coals of fire on the other's head - poured a torrent of hot ashes from a window onto the head of a disinfector who attempted to enter the house. ${ }^{63}$

Clemow implied here that the only solution to the problem was to use the sanitary police and a centralised command structure to enforce the reforms - exactly the same path that İzzeddin followed some three years later when he created the Ottoman sanitary administration.

Still, İzzeddin sometimes ran into difficulties even with his strong institutional presence in the region. This was particularly clear when he tried to regulate the sale, butchering and disposal of sacrificial rams, which the pilgrims bought annually at Mena on the outskirts of Mecca:

The problem in Mena is due to the slaughtering of rams and the overcrowding of the streets. The pilgrims stay in Mena for only three days, but they slaughter hundreds and thousands of rams. Mena is located in a valley, and the pilgrims reside in tents. The majority of pilgrims stay there since the houses are few and very expensive. Unfortunately, the tents are not set up in an orderly fashion and often are set up between the houses. This situation annoys the pilgrims and leads to unhealthy conditions. Thus, the streets should be enlarged and the tents set up in an orderly fashion. The tentmakers should have a map of the places where they should put up their tents. The [campground] should not house more than 1,000 pilgrims and it should be surrounded by a high wall. ${ }^{64}$

He believed that this was an essential task to prevent disease given his claim that there were somewhere between 200,000 and 1 million carcasses to deal with each year at Mena. He recommended that soldiers 'form a cordon between the slaughterhouse and the pilgrims' residences at dawn on the first day of the festival ... [in order to prevent] the slaughter of rams in the pilgrim's tents. Furthermore, he required that 'the sanitary police and physicians inspect the 
rams' before they were sold at a secure slaughterhouse, also supervised by sanitary administrative officials. ${ }^{65}$

The locals, however, balked at the measures, as regulating and taxing their trade in sacrificial rams would lessen their income. In 1910, İzzeddin enforced the new rules only because he ordered Fazil Bey Efendi, the son of Hussein, the Sharif of Mecca, 'to send the Bedouins away with their sheep' ${ }^{66}$ The next year he was not so successful:

It was amazing to see the hostility [of locals] towards Muslim pilgrims and the sanitary services in 1911. Because of this precautions could not be taken against cholera ... Some [newspapers in Istanbul] condemned the attack ... [It occurred] after a quarrel between soldiers and Bedouins broke the cordon established by the divisional general Münir Pasha. The Bedouins then brought in herds of sheep to the pilgrims who slaughtered them. We were not able to bury the rams, and this increased the cholera deaths. ${ }^{67}$

\section{CONCLUSION}

İzzeddin and the Ottoman sanitary reforms soon went into a fatal tailspin. British mechanical support and supplies of coal - so vital to maintaining Jeddah's and Basra's water and electricity - were effectively cut off after the Ottoman entrance into the First World War on behalf of the Central Powers in November 1914. The railway projects to Baghdad and the Hijaz were incomplete, and sufficient supplies and military reinforcements could not reach the sanitary administration due to the British domination of the Red Sea and Persian Gulf. The local population, once enthusiastic about technological improvements, now had to suffer through depravity. The weakness of Ottoman government was on full display. The British replaced Clemow, their friendly representative to the Ottoman Empire, with the likes of Lieutenant J. T. Lawrence ('Lawrence of Arabia') and other British agents, who stirred animosities between the Ottomans and the disaffected Bedouins.

Sharif Hussein and his sons, once İzzeddin's reluctant agents of reform, now worked with Lawrence to stir up the Bedouins, who themselves were embittered by İzzeddin's treatment of them as a diseased people who could be taxed in the name of centralising sanitary reform.

The Arab Revolt of 1916-18 eventually led to political power for Sharif Hussein's progeny: his sons Faisal and Ali took power in Iraq and the Hijaz, respectively. Now it was their turn to run the sanitary administration. Ironically, they both largely followed in the footsteps of their Ottoman predecessors. In Iraq, Faisal passed the Corpse Traffic Law (1924), which followed earlier 
Ottoman controls by severely restricting the pilgrim's import of 'moist corpses'. They were allowed in from outside the country only if they were in 'hermetically sealed ... coffins lined with iron, lead or zinc to the satisfaction of the inspecting doctor at the town of entry' and had a 'certificate from the foreign authorities or from an Iraqi consular officer ... that the corpse had not died from an infectious disease'. In addition, the Iraqis only permitted 'moist corpses' to cross the border between 1 November and 31 March. ${ }^{68}$

Ali tried to re-establish the Abu Saad quarantine station and the facilities in Jeddah, Mecca, Medina and Yanbu, but soon felt the brunt of European disdain:

No effective measures of general sanitation have been taken within the [Hijaz] Kingdom or at the sacred cities, and there is no medical service which in modern eyes could be considered satisfactory. In regard to the ports of the Hijaz, Jeddah and Yanbu, the position is worse than formerly. While the sanitary measures at these ports were undertaken by the Superior Board of Health of Constantinople, they could be applied with due reference to the measures taken in, and information received from, other ports and quarantine stations directed by that board, notably Kamaran. This is not now the case. ${ }^{69}$

He replied in frustration to such reports that he could 'fumigate just as well as the English' ${ }^{70}$ This was a bad sign for Ali's and the Sharif's supporters in the Hijaz. Their Saudi rivals would soon take over the region after Hussein claimed the title of Caliph in 1924.

The Turks faced similar pressures. The British occupied Istanbul after the Ottoman surrender in October 1918. Clemow, who returned with the forces, reported that plague had broken out soon after their arrival:

In Constantinople plague reappeared, after a long absence, in September, 1919. The source of infection was unknown; but the first cases occurred in connection with the granary. Between September and 19 January 1920, fifty-four cases, with nineteen deaths, were registered. After a plague-free interval the disease broke out again in April, and since 24 April, fifty-six cases have been recorded. ${ }^{71}$

A League of Nations commission sent to study the outbreak highlighted the need for the British to take action:

Constantinople town and port itself presents special dangers of epidemic diseases which might have a widespread effect in many countries with which it has sea or land communications. The town and all its outlying parts at the present time are overcrowded, and contain a large alien population, most of which is in a state 
of destitution and malnutrition. Its internal sanitation and health administration, before the war and until the armistice, were entirely in Turkish hands and generally unsatisfactory. The exceptional conditions which arose in Constantinople after the armistice created a very serious state of affairs as regards public health. Since the Allied occupation a number of emergency measures have been taken under the direction of an international committee, and they have been executed under the supervision of a medical officer of one of the Allied forces. Good results have been obtained in several directions. In regards to epidemics, vigorous action has been taken to deal with plague, which appeared in 1919 and still occurs sporadically, and also with epidemics such as smallpox and typhus. For plague, smallpox and cholera, vaccination or preventative inoculation has been carried out on a very large scale. So far as the limited resources and personnel have permitted, attention has been given to the formidable task of sanitary surveillance of refugees. The whole population, estimated at well over 1 million, however, is still without an infectious diseases hospital, without cleansing stations and baths which can deal with typhus and relapsing fever, and without many other primary sanitary requirements. ${ }^{72}$

These claims that the Ottomans neglected 'sanitary affairs and health administration' contrasted sharply with Clemow's praise just before the war for Dr Cemil Pasha (1858-1968), who was head of the sanitary efforts in Istanbul:

The energetic prefect of the city, Dr Djemil Pasha, is not only enlarging the streets and embellishing the quarters of Istanbul, Pera and Scutari, but he is also doing his best to improve the sanitary and hygienic conditions of our metropolis. The municipal authorities did well to elect for this supervising office a capable and travelled physician with studied Western ways and is in touch with modern ideas. His chief plan for the present is to erect a number of new municipal hospitals worthy of the capital, and to enlarge and improve those already in existence. He has prepared a very extensive report on the matter, and hopes to realise this project in the course of five years. ${ }^{73}$

The League of Nations ignored earlier reports of progress and recommended that the remaining Turkish quarantines be 'internationalised' in much the same way as the Suez Canal and Red Sea quarantine systems had been. This is evident in the following article they drafted for a proposed International Sanitary Conference on the subject:

Measures at Constantinople and the Black Sea Ports: ... If and when a port sanitary authority having an international character is established at Constantinople, 
such authority shall make regulations of a similar nature to those authorised in the case of the Sanitary Maritime and Quarantine Board of Egypt ... subject to their acceptance by the powers represented on the authority. The sanitary authority may also take measures in regard to ships from the Black Sea ports which pass through the Bosporus, bound for the Mediterranean, similar to those authorised ... in the case of ships coming from the south through the Suez Canal and bound for the Mediterranean. In pursuance of these duties this sanitary authority shall provide at a suitable station, or stations, near the northern entrance of the Bosporus, all necessary accommodation for medical examination, disinfection, isolation of sick and observation of contacts. ${ }^{74}$

The Turkish independence movement, led by Mustafa Kemal Atatürk (1881-1938), was in no mood to accept such terms. Turkish nationalist forces entered Istanbul in 1923, signalling the end of any significant British presence in the Straits and Anatolia. The British public may have been sympathetic to local Greeks and the initial occupation of the city, but they were loath to maintain any troop commitments after the long and bloody war. Atatürk and the new Turkish government sensed this weakness, and sent İsmet Inönü, Ataturk's right-hand man, to the Lausanne Peace Conference (1923) to draw up a peace treaty between the new state and the victors of the First World War. Inönü successfully defended Turkey's right to run its own quarantine facilities, and even nationalised the Constantinople Superior Health Council.

The Ottoman Empire's eighty-year experiment in quarantines and sanitary administration had ended with mixed results. The Istanbul quarantine was consistently successful in defending Ottoman interests in the Straits through the government's control of the Constantinople Superior Health Council and the popular support reformers like Hamdan and Ahmed Midhat had garnered. But İzzeddin's sanitary administration's attempt to cement Arab-Turkish ties could not ultimately subjugate the Bedouins of the Hijaz and the Shiites of southern Iraq. Clemow and the British withdrew their support for these efforts after the war broke out and rebellions ensued. Thus, the Ottomans had learned a bitter lesson about quarantine reform: it could help consolidate a republic but not an empire.

\section{NOTES}

1. Meclis-i Umur-1 Tibbiye-i Mülkiye ve Sıhhiye-i Umumiye, Veba, p. 24.

2. Meclis-i Umur-1 Tibbiye-i Mülkiye ve Sıhhiye-i Umumiye, Veba, pp. 7-8.

3. Dr F. G. Clemow, 'Cholera, the Haj, and the Hedjaz Railway', The Lancet 20 February 1909, pp. 577-78.

4. Ministére des affaires étrangères, Conférence Sanitaire Internatiionale de Paris: 7 Novembre 1911-17 Janvier 1912: Procès-verbaux, pp. 432, 434. 
5. Ruhi Al-Khailidi's relative Nazif Bey al-Khalidi (1875-1916) was a key engineer for the Hijaz Railway, helping to construct the main railway terminal in Damascus and lines in what is now modern-day Syria and Jordan. William Ochsenwald, The Hijaz Railway, p. 34. See also see: Hasan Kayal1, 'Arabs and Young Turks: Ottomanism, Arabism, and Islamism in the Ottoman Empire, 1908-1918', pp. 104-5.

6. Dr Bartoletti, Rapport sur les Measures à Prendre Contre la Peste Qui Sévit en Perse, pp. 3-11.

7. Tholozan, Histoire de la Peste Bubonique, pp. 1-42.

8. Simpson, A Treatise on Plague, p. 436.

9. Dr F. G. Clemow, 'The Shiah Pilgrimage and the Sanitary Defences of Mesopotamia and the Turco-Persian Frontier', The Lancet 12 August 1916, p. 290.

10. Clemow, 'Shiah Pilgrimage', 2 September 1916, p. 442.

11. Clemow, 'Shiah Pilgrimage', 19 August 1916, p. 334.

12. Clemow, 'Shiah Pilgrimage', 19 August 1916, p. 334.

13. Clemow, 'Shiah Pilgrimage', 9 September 1916, p. 490.

14. Clemow, 'Shiah Pilgrimage', 2 September 1916, pp. 442-3.

15. Clemow, 'Shiah Pilgrimage', 9 September 1916, pp. 490-1

16. Clemow, 'Shiah Pilgrimage', 12 August 1916, p. 293; 2 September 1916, p. 442.

17. Clemow, 'Shiah Pilgrimage', 12 August 1916, p. 290.

18. Clemow, 'Shiah Pilgrimage', 2 September 1916, p. 442; 12 August 1916, p. 290.

19. Clemow, 'Shiah Pilgrimage', 9 September 1916, p. 490.

20. Cassim İzzeddine, Le Pèlerinage Chiite et l'Hygiène, pp. 43-61.

21. İzzeddine, Le Pèlerinage, p. 6.

22. Clemow, 'Shiah Pilgrimage', 12 August 1916, p. 290.

23. Lamec Saad, Sechsen Jahre als Quarantänearzt in der Türkei, p. 63. I want to thank Dr York Norman for translating the relevant passages from this text from German to English.

24. Ministére des affaires étrangères, Conférence Sanitaire Internatiionale, p. 801.

25. Ministére des affaires étrangères, Conférence Sanitaire Internatiionale, p. 797.

26. Dr F. G. Clemow, 'The Sanitary Defence of the Hedjaz Railway', The Lancet 24 October 1908, p. 1250.

27. Clemow, 'The Sanitary Defence of the Hedjaz Railway', 7 November 1908, p. 1406.

28. Clemow, 'The Sanitary Defence of the Hedjaz Railway', 10 October 1908, p. 1104.

29. Ochsenwald, Hijaz Railway, pp. 138-9.

30. Ministére des affaires étrangères, Conférence Sanitaire Internatiionale, p. 270.

31. Proust, La Défense de Europe, pp. 242-3.

32. İzzeddin, Hicaz'da Teskilat (1329), pp. 11-12.

33. Michael C. Low, 'Empire of the Hajj: Pilgrims, Plagues and Pan-Islam under British Surveillance, 1865-1926', pp. 102-3.

34. Proust, La Défense de Europe, p. 243.

35. İzzeddin, Hicaz'da Teşkilat (1329), pp. 64-7.

36. The Hijaz Railway had an annual budget of ranging between $1,033,465$ paistres (1903) and 3,975,443 paistres (1908). Ochsenwald, Hijaz Railway, p. 80.

37. İzzeddin, Hicaz'da Teskilat (1329), pp. 13, 36, 47-9.

38. İzzeddin, Hicaz'da Teşkilat (1329), pp. 47-9.

39. İzzeddin, Hicaz'da Teşkilat (1330), pp. 3, 27-8, 64, 76-81; Kayal1, 'Arabs and Young Turks', pp. 165-8. 
40. Dr F. G. Clemow, 'Some Turkish Lazarets and Other Sanitary Institutions in the Near East', The Lancet 29 June 1907, p. 1811.

41. İzzeddin, Hicaz'da Teşkilat (1329), p. 40.

42. İzzeddin, Hicaz'da Teskilat (1329), pp. 76-81.

43. Low, 'Empire of the Hajj', pp 102-3.

44. Clemow, 'Turkish Lazarets', 29 June 1907, pp. 1811-12; 6 July 1907, pp. 51-2; F. G. Clemow, Le Eaux de Djeddah, pp. 3-7.

45. Clemow, Le Eaux de Djeddah, p. 7.

46. Clemow, 'Turkish Lazarets', 6 July 1907, p. 52.

47. Clemow, 'Turkish Lazarets', 6 July 1907, p. 52.

48. İzzeddin, Hicaz'da Teskilat (1330), pp. 76-81.

49. İzzeddin, Hicaz'da Teşskilat (1330), p. 42.

50. İzzeddin, Hicaz'da Teskilat (1330), p. 51.

51. Ochsenwald, Hijaz Railway, p. 99.

52. Donald Quataert, The Ottoman Empire, 1700-1922, front cover.

53. İzzeddin, Hicaz'da Tesskilat (1330), pp. 51, 61.

54. İzzeddin, Hicaz'da Teskilat (1330), p. 61.

55. İzzeddin, Hicaz'da Teskilat (1330), p. 64.

56. York Norman, 'Are Muslims "Jews" or "Gypsies"? A Reassessment of Bosnian Muslim Political Thought under the Habsburgs', p. 4. I thank Dr Norman for letting me read his unpublished work.

57. İzzeddin, Hicaz'da Teskilat (1330), pp. 54, 56.

58. Dr F. G. Clemow, 'Egypt', The Lancet 10 March 1906, p. 718.

59. İzzeddin, Hicaz'da Tesskilat (1330), 56.

60. İzzeddin, Hicaz'da Teskilat (1330), pp. 24-5, 60-1.

61. İzzeddin, Hicaz'da Tesskilat (1330), pp. 24-5.

62. Clemow, 'Turkish Lazarets', 4 May 1907, p. 1253.

63. Clemow, 'Turkish Lazarets', 4 May 1907, p. 1253.

64. İzzeddin, Hicaz'da Teskilat (1329), 45-6.

65. İzzeddin, Hicaz'da Teskilat (1330), 24-5.

66. İzzeddin, Hicaz'da Teşkilat (1329), pp. 78-9.

67. İzzeddin, Hicaz'da Tesskilat (1330), p. 137.

68. Anja Pistor-Hatam, 'Pest und Cholera: Die Wahlfahrt zu den Heilegen Stätten im Irak als gesundheitspolitisches Problem im 19. Jahrhundert', pp. 243-4.

69. League of Nations, Report of Commission, 20 February-27 March 1922, p. 8.

70. Sean Foley, The Arab Gulf States: Beyond Oil and Islam, p. 215.

71. Dr F. G. Clemow, 'Plague in Turkey during the War', The Lancet 20 November 1920, p. 1065.

72. League of Nations, Report of Commission, 20 February-27 March 1922, pp. 11-12.

73. Dr F. G. Clemow, 'Constantinople', The Lancet 28 March 1914, p. 927.

74. League of Nations, Report of Commission, 20 February-27 March 1922, pp. 22-3. 